\title{
The Lexical Characteristics of Jane Eyre
}

\author{
LiuChunling \\ (School of Foreign Languages, Wuhan Polytechnic University, Wuhan, 430024, China)
}

\begin{abstract}
Jane Eyre is a famous masterpiece of Charlotte Bronte. The novel's literary achievement is immortal, especially the brilliant language. The description not only brings readers aesthetic pleasure but also hint the fate and emotion of characters. Charlotte's original description forming a colorful picture makes Jane's image more perfect and vivid and drives readers to search more for the beauty of the novel and the life. Moreover, Charlotte endows words with indefinite sense and deep connotation. This thesis aims to explore the lexical characteristics on the theory of linguistics.
\end{abstract}

Key words: colorful words; connotative meaning; landscape description

\section{Introduction}

Jane Eyre is a realist novel with romantism, which is the bittersweet story about the life of a purposeful and passionate young woman, who survives a wretched childhood to become a governess and falls deeply in love with her troubled but compelling employer, Mr. Rochester. Scandalous revelations wreck their wedding day and send her fleeting. After soul-searching, she returns to the aftermath of tragic events to a reunion that allows her to enjoy the true happiness. It has been studied from the view of literary appreciation or of literary criticism, but the lexical characteristics.

\section{The Lexical Characteristics of Jane Eyre 1. The Appreciation of Colorful Words}

We cannot live without colors (red, orange, green, blue, and purple, etc.) and different colors are definitely different according to different occasions. The author applies colorful words to indicate the change of character's destiny. Jane Eyre has been portrayed successfully who was brave enough to rebel against the unfair reality and to fight for her own freedom and happiness. Charlotte realized wisely that environmental description had an emphasis on the development of the plots and demonstrates the heroine's hopeless rebellion as well as frustrations,

In Chinese traditional culture, red is a warm color and it always represents happiness and good luck. However, red is a stifling color in the masterpiece. Jane was born in a humble family, and her parents died when she was very young. Since her aunt adopted her, she began to live in a forlorn life in the Boarding School until she became an adult as the people around her couldn't get on well with her. There are many descriptions about her childhood, but what makes a great impression on readers is that she was locked in the red room by her aunt after she had confliction with her cousin."It was one of the largest and stateliest chambers in the mansion. A bed supported on massive pillars of mahogany, hung with curtains of deep redda mask, stood out like a tabe macle in the center.....the carpet was red, the table at the foot of the bed was covered with a crimson cloth; the wall were a soft fawn color, with a 
blush of pink in it, the wardrobe, the toilet-table, the chairs, were of darkly-polished old mahogany. One of these deep surrounding shades roses high, and glared white, the pile-up mattresses and pillows of the bed, spread with a snowy Marseilles counter pane. Scarcely less prominent was an ample cushioned easy - chair near the head of the bed, also white, with a foots tool before it, and looking as I thought, like a pale throne."

When Jane went to Lowood Boarding School, she still had the tragic life, especially during the previous period of time: malnutrition, shoddy clothes and equipment, etc. The only color in her life was the girl's brown clothes and the gray sky beyond the tall wall. The adolescent girl should be decorated more flamboyant. In fact, there are only the shackled hearts behinds the dull and dismal colors. But the manmade shackles couldn't change the case of the growth and they also couldn't be against the youth and the hope of the future. With her growing and the improving environment, Jane becomes much more mature as there is a trace of "green" exists in her life. "April advanced to May - a bright serene, may it was days of blue sky, placid sunshine, and soft western or southern gales filled up its duration. And how vegetation matured with vigor Lowood School loose its tresses, it became all green all flowers." The torrent of life was flowing, defeating the severe winter and greeting the coming spring. "Green" symbolizes freedom and hope, and it's also the girl's expectation of her bright future, the fantastic maid hood.

It's said that young girls like dreaming and "blue" is just the color of the dream. Maybe every girl as Jane is eager to expect that beautiful sunshine comes into her own room through the blue curtains. Though our plain heroine was only a tutor, it's a new start when she came to Thornfield. She got rid of the dullness and depression of Lowood Boarding School and began to breathe the fresh air. At that moment, she must be full of enthusiasm, thinking that she was coming into a better period of her life, a period overflows fragrance together with thorn, and a period brims over fresh flower and delight. All her organs were awakening and she was expecting some pleasant things coming. On account of the blue curtains, she also had a romantic dream. In addition, the journey of love is not a bed of roses so blue predicts that Jane's love won't be smoothly and must be accompanied with melancholy.

Drawing the Thornfield's curtain open, we can see a picture combing snow and fire together. This was Jane's first impression on rest rooms in Thornfield. "...... white carpets, on which seemed laid brilliant garland of flowers, both ceiled with snowy mouldings of white grapes and vine leaves, beneath which glowed in rich contrast crimson couches and while the ornaments on the pale pariah mantelpiece were of sparkling Bohemain glass ruby red." The thick red reflects the passionate love and love brings warmth and power to the two suffering souls. "white" which is pure mixes with red in the heart of a complete mature girl. It's just like the plum blossom in snow and Jane seemed to forget all the distress of her childhood and she was buried in the sweetness of love. There's no doubt that she sighed with "I think, I really get a glimpse of the fairyland."

The author describes the surroundings from different perspectives and directions: the blue sky, the woods bathed in the sunshine, pasture, green hills, glowing and bright sun, and the solemn purple color after sunset, the solemn house and the crows' nest. Since Jane made acquaintance with Mr. Rochester, her life was full of sunshine and she first experienced the 
waited wild joy and happiness of love and being loved. "Green" is the background color and a keynote. Thornfield is surrounded with the green color, the garden, the crops, the trees, and the green hills. All of these things are colored with green. Green is the color of life and may we live in the green of ourselves. We can imagine that when Jane was forced to leave the green, she must be

tortured. As she said: "Just like a capital criminal forced to the guillotine, life passed away at the same time."

\section{Connotative Meanings of Thornfield}

It's generally believed that the heroine spends her miserable childhood in Boarding School and gets happy life in "Thornfield" as she makes friends with the servants and received love from Adele and Rochester, etc. According to the definition, "Thornfield" is a place loaded with troubles and difficulties. That the most important part of the plot sets in here is not accidental, but deliberate.

With great hope for the future, Jane left Lowood for Thornfield where Jane's life plunged into irritation and perplexity. The day after her arrival, she is shown around by the housekeeper. "I lingered in the long passage to which this led, separating the front and back rooms of the third storey-narrow, low and dim...While I placed softly on, the last sound I expected to hear in so still a religion, a laugh, struck my ears. It was curious laugh-distinct, formal, mirthless,...The laugh was repeated in its low, syllabic tone, and terminated in an odd murmur." Jane was not familiar with the house, yet she heard the laugh. We can imagine her perplexity besides surprise. It was noon when ghosts didn't appear but Jane reminded of them. The incidence makes Jane feel quite ill at ease. Then she lives there with caution, as if walking through a thorn field, bare-footed.
In this mysterious place, strange incidents happen one after another and Jane's life id frequently threatened. Mason is the visitor injured and she is asked to take care of him. Jane described the scene as "...a pale and bloody spectacle under my eyes and hands...". On a deep night, a weak woman takes care of an injured man alone, with the criminal locked the next door." The most astonishing event happened the night before her wedding day. Jane saw "a woman, tall and large, with thick and dark hair hanging long down her back...the lips were small and dark; the brow furrowed, the black eyebrows widely raised over the bloodshot eyes...removed her veil from the gaunt head, rent it in two parts, and flinging both on the floor, trampled on them." The mystery often appearing suddenly in the still of deep night, in the form of fire or blood has greatly threatened Jane's life. These incidents stab her heart and fill her life with great trouble and fear who can endure this, besides the brave and strong-willed Jane.

Jane fell in love with Rochester, but she suffered pain and humiliation due to distance in social status. When Rochester was out, Jane supposed that he was meeting the notable and rich Miss Ingram, and expected his return anxiously. When she thought that Mr. Rochester was going to marry the charming Miss Ingram, she was almost mad with pain and despair. Finally, she drawed two pictures, one of Miss Ingram, the other of herself and added "the versatile notable Branch" and "lonely plain governess" respectively and forced herself to drench the fire of the love. Jane loved Mr. Rochester, but she couldn't express the feeling and even forced herself to finish the love journey. At the wedding ceremony, Maston appeared and destroyed her happiness thoroughly. With the spirit of rebellion and the 
pursuit of equality and self-dignity between male and female, Jane left Rochester. Having experienced so much, she often suffered from insomnia and nightmare. Charlotte explained why she calls it "Thornfield" by Rochester's words. "If the place was called "peacefield", "flowerfield" or "joyfield", it would be disagreeable with the atmosphere and the content of the novel." Jane Eyre is famous not only because of its unique content and touching plot, but also because the author gives abundant connotation to the name of the place. Only through both physical and mental test does Jane become mature and get real happiness.

\section{Imagery Beauty of Landscape Description}

Imagery is a mixture of rationality and emotion presented instantaneously in literary works. During the process of combining the outer objects description with the inner world expression, imagery let readers have vast and free aesthetic space. The landscape description conspicuously exhibits the novel's beauty of imagery. The author describes and regards the natural phenomena such as "fire", "moon", "wind", "frost", "rain", "snow" and "frog", etc. from a unique vision with sharp eyes. The landscape description functions as either conveying the heroine's even slight and complex psychological sensation, or indicating the character's fate, or implicating the symbolic scene of religious culture. With the substantial content and perfect form, the novel has possessed an eternal charm.

"Fire", the symbol of human civilization, is a necessity in life. It is mentioned for several times and represented different meanings. As a line of the novel, it plays an important role in portraying the courses of the development of love between Jane and Mr. Rochester and the growth of the heroine. In other words, Charlotte doesn't describe the fire itself but to explore its cultural and religious implication. For example, "...its cloud strata high and thin. The west, too, was warm: no watery gleam chilled it-it seemed as if there was a fire lit, an altar burning behind its screen of marbled vapor, and out of apertures shone a golden redness." Fire connotes hope, showing Jane's longing for peace and love. Because of the bitter experience in childhood, the author describes Jane as a woman pursing freedom, equality and happiness. "Stove fire" symbolizes cozy home and happy life. The fire can be bright, jubilant, magnificent, wonderful, inspiring and generous. After Jane was charged by false and published by Brocklehurst, the kind Miss Temple, the superintendent, listens to Jane and leads Jane and Helen to her own room. "... it contained a good fire, and looked cheerful...placed on the round table near the fire...The refreshing meal, the brilliant fire!" Hope appears in the love-barren school, showing care and symbolizes Miss Temple's love, friendship and enthusiasm. Fire gives Jane and Helen warmth and comfort.

The moon is usually loaded with profound symbols. The most wonderful part is the moon before the wedding day. "As I looked up at them, the moon appeared momentarily in the part of sky which filled their fissure; her disc was blood-red and half overcast; she seemed to throw on me bewildered, dreary glance, and buries herself again instantly in the deep drift of cloud." The moon is not as bright and tender as usual. The blood-red moon, quite unsettling, forecasts Jane's unfortunate experience the next day. In western culture, "red" means passion and desire. Red is also the color of blood, suggesting violence and danger. The moon is endowed with mythological and religious sense. 


\section{Conclusions}

The thesis aims to re-appreciate the masterpiece by analyzing the lexical characteristics of Jane Eyre. Jane was an ordinary woman, but the author arranged extraordinary experience and changeable fate with colorful words. From the name of Thronfield, readers can give insights into hidden implications with enlightment and speculation. Besides, the landscape description functions either conveying the heroine's minor and complex psychological sensation.

\section{References:}

[1] Wu Xueqiong. A Unity of Contradictions-An Analysis of Jane Eyre's Character. Overseas Engligh, 2012 (3).

[2] Sun Yingying. Jane Eyre:A Rebellious Woman. Reading and Writing, 2010(11).

[3] Liang Ying. Interpretation of Jane Eyre. Science and Technology Information, 2009 (18).

[4] Yang Xiaojing. Jane Eyre: Contradictions in Women. Anhui Literature, 2007 (4).

[5] Pan Wentao. Significance of Jane Eyre's Independence. Overseas Engligh, 2014 (6). 